\title{
The Journey of Finding Meaning in Life: Posttraumatic Growth Experience in Notable Holocaust Survivors
}

Sri Wulandari ${ }^{\mathrm{a}}$, Elizabeth K. Poerwandari ${ }^{\mathrm{b}}$, and Augustine A. Basri ${ }^{\mathrm{c}}$

${ }^{a}$ Faculty of Psychology, Universitas Indonesia, Depok, Indonesia; ${ }^{b}$ Department of Clinical Psychology, Faculty of Psychology, Universitas Indonesia, Depok, Indonesia; ${ }^{c}$ Department of Clinical Psychology, Faculty of Psychology, Universitas Indonesia, Depok, Indonesia

*Corresponding author:

Elizabeth K. Poerwandari

Department of Clinical Psychology

Faculty of Psychology, Universitas Indonesia

Jl. Lkr. Kampus Raya, Depok, Jawa Barat

Indonesia, 16424

Tel.: +62 217270004

Email address: elizabeth.kristi@ui.ac.id 


\title{
The Journey of Finding Meaning in Life: Posttraumatic Growth Experience in Notable Holocaust Survivors
}

\begin{abstract}
Posttraumatic growth (PTG) refers to the occurrence of positive psychological changes following a traumatic event. The Holocaust was one of the most traumatic events in modern civilization, yet many Holocaust survivors have found meaning even in this painful experience, and their search for and discovery of meaning in life has been an important part of their journey toward positive change. Few studies have closely examined survivors' perspective on how the process of searching for and finding meaning in life helped them to experience PTG. In this study, we applied the method of psychobiography to analyze the autobiographies of Viktor Frankl and Elie Wiesel, using a film documentary and Internet articles for data triangulation. Theoretical conceptions of PTG and of meaning in life were used as a framework to interpret the autobiographies. The analysis determined that Frankl and Wiesel demonstrated positive development in every domain of posttraumatic growth. The process of discovering newfound meaning was central in their PTG experiences. Differences between their personal journeys may be attributable to background factors such as their age, previous exposure to Nazism, personal characteristics, and camp experiences. Clinicians could use the results of this study to foster PTG in their therapeutic work or, in broader settings, to help people in societies with histories of mass violence or genocide to cope with their trauma.
\end{abstract}

Keywords: Holocaust, posttraumatic growth, life narrative, presence of meaning, searching for meaning

\section{Introduction}

Posttraumatic growth can be defined as the positive psychological changes that an individual experience as a result of his or her struggles in dealing with highly challenging life circumstances (Calhoun \& Tedeschi, 2001). The term trauma refers to circumstances that one perceives as highly stressful life events or as constituting a major life crisis. Posttraumatic growth has several characteristics that differentiate it from related constructs (Tedeschi \& Calhoun, 2004) such as hardiness (Kobasa, 1979) or resilience (Rutter, 1987). First, posttraumatic growth must follow an experience that is perceived as very challenging and exceeds one's ability to endure. Second, this challenging circumstance not only induces negatives feeling or stress but also threatens or even shatters the individual's fundamental assumptions about life. Third, the reaction that emerges from encountering the circumstances is not merely a coping mechanism or a return to the baseline condition; rather, the growth should go beyond the capacity that the individual possessed before the traumatic event. Posttraumatic growth is manifested in five domains (Tedeschi, Cann, Taku, Senol-Durak, \& Calhoun, 2017): (1) increased sense of personal strength, (2) closer and more meaningful relationships with others, (3) awareness of new possibilities, (4) greater appreciation of life, and (5) spiritual and existential change. 
The presence of the trauma does not directly result in growth, but rather serves as a catalyst for the growth (Calhoun \& Tedeschi, 2001, 2006; Tedeschi \& Calhoun, 2004). Traumatic events severely challenge an individual's understanding of, perspective on, and way of interpreting life. When this old schema no longer fits the present circumstances, cognitive restructuring takes place to accommodate the aftermath of the crisis as the new reality. At this point, the individual struggles to build a new schema that incorporates the trauma, possible future events, and his or her changed understanding of reality. This new schema must be more resistant so as to withstand severe threats and challenges. This emergence of a new schema as a result of cognitive struggling is the essence of posttraumatic growth.

In Joseph and Linley's conceptualization (2005) of how positive change occurs after a traumatic event, finding meaning is central to cognitive-emotional processing (Linley \& Joseph, 2011). The traumatic event disrupts individuals' understanding of life, the world, and their place in it, sometimes leaving victims with a sense of meaninglessness (Triplett, Tedeschi, Cann, Calhoun, \& Reeve, 2012). This state of meaninglessness forces individuals to work through their crisis and search for new sources of meaning, significance, and purpose in their lives (Steger, Frazier, Oishi, \& Kaler, 2006; Steger, Oishi, \& Kashdan, 2009). Survivors of the traumatic event may first ruminate on questions about the meaning of life itself, but later the questions shift to finding meaning in their own lives (Janoff-Bulman, 2006). The presence of perceived meaning may indicate that some degree of resolution has been reached, i.e., that the view of one's self and the world has been reconstructed and a new assumptive world has begun to emerge (Linley \& Joseph, 2011). At this point, the individual has found direction to continue the life that was indelibly altered by the traumatic event (Triplett et al., 2012).

Meaning in life is not a new concept in the field of philosophy and psychology. However, viewing the process of finding meaning in life as an important part of psychological growth following adversity became more popular after the appearance of Viktor Frankl's book Man's Search for Meaning (1985). Research on meaning in life almost always cites Frankl's work, which was inspired by his experience as a Nazi prisoner during World War II. According to Frankl (1985), the people who were most able to function in and survive their horrible life in a concentration camp were those who had a clear sense of meaning and life purpose. In fact, his favorite quotation came from Nietzsche: "He who has a way to live can bear almost any how."

Meaning of life is conceptualized as "the sense made of, and significance felt regarding, the nature of one's being and existence" (Steger et al., 2006). Although the terms meaning and purpose are often treated as interchangeable, these two concepts are not equivalent. Meaning is a broader concept comprising three dimensions: coherence, purpose, and significance (Martela \& Steger, 2016; Steger et al., 2009). Coherence is defined as an individual's ability to make sense of and comprehend one's life, self, and external world and how one fits into and operates within the world. Purpose is the long-term aims and aspirations that direct an individual to pursue relevant activity. Finally, significance is an individual's sense of life's inherent value and a belief that life is worth living. 
Many survivors of the Nazi Holocaust have left a great legacy for humanity by demonstrating the ability to find meaning even in the most painful and traumatic experiences, thereby laying the foundation for psychological growth (Frankl, 1985; Lev-Wiesel \& Amir, 2003). Meaningmaking gave some Holocaust survivors a strong motivation to rebuild their lives in a positive manner, such as by participating in social activities, writing books, or raising families. These examples suggest that in some cases, survivors' schemas of themselves, their world, and their lives may have been positively modified following the Holocaust (Danieli, 2007). In other words, searching for and finding new meaning in life helped the survivors to experience posttraumatic growth.

Among the inspiring stories of Holocaust survivors, those of Viktor Frankl and Elie Wiesel are two of the most prominent. Frankl was widely known not only as author of Man's Search for Meaning, but also as a neurologist and psychiatrist as well as a key figure in the existential approach to psychotherapy. Moreover, Frankl was the founder of Logotherapy, a form of psychotherapy that emphasized finding meaning in life. Elie Wiesel was also a celebrated writer and humanitarian activist. His book Night (2006) was an acclaimed bestseller, translated into many languages, and a seminal work on the terrors of the Holocaust. Wiesel was awarded the Nobel Peace Prize in 1986; the Nobel citation honoring him regarded him as "a messenger to mankind."

Although many conceptual and empirical works have examined posttraumatic growth and meaning in Holocaust survivors, few of them have explored how survivors' life in the concentration camps led to the process of searching for meaning, how they came to find new meaning in their lives, or how their newfound meaning helped them to experience psychological growth. The study of survivors' autobiographies allows us to explore these questions in a more in-depth and reflective manner, leading to a deeper understanding of the human mind and functioning as well as promoting self-awareness in the reader (Kovary, 2011). Furthermore, the three-dimensional conceptualization of meaning in life referenced above (Martela \& Steger, 2016) is a relatively new concept and has been explored only at the theoretical level.

Although in this paper posttraumatic growth and meaning of life were studied in the context of the Holocaust, the issue is generalizable to other contexts. In many parts of the world, including Indonesia, social and political conflicts is a prominent part of the national history or continues to this day, forcing people to deal with the past and present horrors of violence and even genocide. Though the scale of such incidents is smaller than that of the Holocaust, the psychological aftermath affects the survivors and their societies in similar ways. Moreover, research has suggested that growth can occur in the aftermath of a variety of life crises (Tedeschi, Calhoun, \& Groleau, 2015), including natural disasters or the death of a loved one. Hence, the principle of posttraumatic growth can be studied in one context and then applied so as to promote growth in other contexts.

Therefore, this study examines the autobiographies of Viktor Frankl and Elie Wiesel to answer several questions. First, based on their experiences, in what domain(s) did their 
posttraumatic growth occur? Second, how did their experience in a concentration camp set in motion their process of searching for and finding meaning? Third, what differences in these two people's backgrounds and experiences may have contributed to the differences between their journeys?

\section{Method}

This study used the methodological approach known as psychobiography. According to Elms (2007) and du Plessis (2017), research using psychobiography is carried out in several steps. First, one must choose the subject to be studied. Generally, psychobiographies focus on individuals who have attained significant accomplishments and/or fame in a particular area. Second, one formulates tentative hypotheses about a potential subject and collects initial data from various sources. The third step is to revise the tentative hypotheses based on the data so as to identify a more specific psychological construct to be studied. Usually, data collection is limited to several sources and primarily to the subject's own writing and oral testimony, since these sources convey most fully the subject's point of view regarding his or her own life. If discrepancies arise across the sources, the psychobiographer turns to secondary sources. The fourth step is to extend the iterative research process until the psychobiographer can determine conclusions.

This study conducted a descriptive analysis of the autobiographies of Viktor Frankl (Man's Search for Meaning, 1985) and Elie Wiesel (All Rivers Run to the Sea, 2010). We also reviewed Wiesel's earlier book Night, to which he often referred in his autobiography when discussing his life in the concentration camp. A documentary film (Vesely, 2010) and Internet articles were used for data triangulation. We focused on Frankl and Wiesel's subjective interpretations of life in the camp and compared those interpretations with their lives before and after the camp. The theory of posttraumatic growth (Tedeschi \& Calhoun, 2004) was used as a conceptual framework for the analysis. Frankl and Wiesel were purposefully chosen for analysis because both were well-known Holocaust survivors with influential and internationally recognized professional works. Moreover, their thorough narratives are among the best depictions of the life of a Nazi concentration camp prisoner. Hence, these works may help us to understand the psychological mechanisms of other people undergoing similar experiences.

\section{Result}

\section{A. Domain of Posttraumatic Growth}

Frankl and Wiesel grew in all five domains of posttraumatic growth, as evidenced in their narratives. First, they showed an increased sense of vulnerability and personal strength. Both of them witnessed the murder of their immediate family members, relatives, and other fellow prisoners. They themselves were victims of torture. These experiences caused them to realize how weak and vulnerable humans are, how human lives could be treated as worthless, and how easy it was for some people to take other people's lives. However, the very fact that they survived these experiences also brought an awareness of mental strength that enabled them to endure the torments. Frankl (1985) wrote: 


\begin{abstract}
"But for every one of the liberated prisoners, the day comes when, looking back on his camp experiences, he can no longer understand how he endured it all. As the day of his liberation eventually came, when everything seemed to him like a beautiful dream, so also the day comes when all his camp experiences seem to him nothing but a nightmare. The crowning experience of all, for the homecoming man, is the wonderful feeling that, after all he has suffered, there is nothing he need fear any more-except his God." (p. 115).
\end{abstract}

Second, their experiences of losing everything, especially most of their family members, made Frankl and Wiesel very grateful for the relatives and friends they rediscovered after their camp was liberated. For example, Wiesel felt a mixture of disbelief and gratitude upon learning that two of his sisters and his cousins were still alive. The reunion was very touching for him, as he realized that he was now an orphan living in a lonely world and that his two sisters and cousins were the only close family members he had left. He also found a deep connection with other children and adolescent survivors whom he met during his stay at an OSE house (Oeuvre de Secours aux Enfants, or Children's Aid Society in English) in France soon after his liberation. Coming from a Jewish background and being a Holocaust survivor, Wiesel felt commonalities with these OSE fellows that caused him to grow close to them.

Frankl, meanwhile, developed close connections with other prisoners, including a former assistant surgeon who worked with him at a construction site. He trained this friend to develop his sense of humor by asking him to tell one amusing story each day. In this way, Frankl tried to help him experience joy in the midst of their suffering.

Third, both men felt a greater appreciation for life and for many aspects of it, along with a sense that they were lucky to be alive when so many others had died. Although at first, immediately after their liberation, freedom felt unreal to them, they came to appreciate the privilege of not being a prisoner anymore, and even the smallest joy they experienced was meaningful. Frankl (1985) wrote:

"One day, a few days after the liberation, I walked through the country past flowering meadows, for miles and miles, toward the market town near the camp. Larks rose to the sky and I could hear their joyous song. There was no one to be seen for miles around; there was nothing but the wide earth and sky and the larks' jubilation and the freedom of space. I stopped, looked around, and up to the skyand then I went down on my knees. At that moment there was very little I knew of myself or of the worlds-I had but one sentence in mind-always the same: "I called to the Lord from my narrow prison and He answered me in the freedom of space." How long I knelt there and repeated this sentence memory can no longer recall. But I know that on that day, in that hour, my new life started. Step for step I progressed, until I again became a human being. ”.

Fourth, the suffering that Frankl and Wiesel endured in the concentration camp helped to raise their awareness of new possibilities in life, leading them to develop new life missions. 
Frankl had been a renowned psychiatrist even before the Holocaust, but afterwards he developed his well-known approach known as Logotherapy, which caused his work to become known as the Third Viennese School of Psychotherapy, following Freud and Adler. Logotherapy sought to help people solving their problems by guiding them to find meaning in life. This method was largely based on Frankl's personal experiences of struggle during his concentration camp years. Wiesel adopted the life calling of promoting peace and humanity through his writing and campaigns. His works gained him recognition as "a messenger to mankind..." Not only did he spread the message of peace but he also encouraged citizens throughout the world to realize that they have the power to stop terror, oppression, and racism. Wiesel tried to help people learn from Holocaust, arguing that it happened because too many people chose to stay silent and maintain neutrality. Wiesel believed that neutrality was only an excuse and that others can be of great help should they choose to voice their concern (Wiesel, 1986).

Fifth, both men grew in the spiritual domain (Tedeschi \& Calhoun, 2004). For Frankl, spiritual growth came as a result of experiencing various coincidences that kept him alive. For example, he was standing in one of two lines, but something suddenly made him move to the other line. Only later did he learn that prisoners in his initial line were to be exterminated in the gas chamber. Another fortuitous event occurred when he was chosen for transfer to another concentration camp, where Frankl survived while most of the prisoners in his previous camp died of hunger. Yet another coincidence occurred near the time of liberation, as some of his close friends plotted an escape from the camp but he chose not to join this mission. As it turned out, his friends were caught and killed, just days before the camp was liberated by U.S. troops. Frankl believed that these coincidences were not simply a result of random chance, but that he had been destined to survive the concentration camp. He believed that when one is destined to die, no matter what that person does to try to escape, he or she will eventually meet death; conversely, those destined to survive will endure.

Wiesel's experience of witnessing cruelty and death made him question humanity and God. In Night (2006), he recounted the story of the hanging of a young Jewish boy:

"But the third rope was still moving: the child, too light, was still breathing. ... And so he remained for more than half an hour, lingering between life and death, writhing before our eyes. And we were forced to look at him at close range. He was still alive when I passed him. His tongue was still red, his eyes not yet extinguished. Behind me, I heard the same man asking: "For God's sake, where is God?" And from within me, I heard a voice answer: "Where He is? This is where-hanging here from this gallow." (p. 64-65).

However, in his autobiographies, Wiesel explained that he never actually renounced his faith. His anger, protest, and questions of God rose up within his faith and not outside it. He accepted that suffering and death were what God intended for the Jews. The pain he felt was part of the test of his faith in God, and this experience transformed his naïve faith. 


\section{B. Searching for Meaning and Presence of Meaning}

Searching for meaning in life entails looking at the subjective experiences of human beings and asking what causes them to experience meaningfulness in their lives (Martela \& Steger, 2016). Human beings who sense the presence of meaning have interpreted their experiences in such a way as to make them meaningful.

In his autobiography, Frankl did not state what his sense of meaning in life was before he entered the camp. However, his description of camp life shows that what he witnessed and experienced there shattered his schema about life in general. In his attempt to search for meaning in his new circumstances, Frankl came up with numerous philosophical questions. How did the prisoners become accustomed to life in the camp? What enabled some prisoners to survive while others did not? Did man have free will in the face of such circumstances? What was the psychological makeup of the camp guards? How was it possible for men to treat others so horribly?

Frankl found the answers for his questions through his intimate observations and conversations with his fellow prisoners. Furthermore, his ability to reflect on his own thoughts and feelings also helped him to comprehend his life, his self, and his external world. While still in the camp, he reached the conclusion that regardless of the circumstances, human life actually never ceases to have meaning. A man, Frankl determined, will accept his suffering when he finds that to suffer is his destiny. However, what differentiates one man from another is the way in which this man accepts his fate and all the suffering that follows. This response gives him the opportunity to add deeper meaning to his life. Even under the most difficult situations, this truth remains, for in the most difficult circumstances lies the decision whether to make use of or abandon opportunities to explore and attain meaning in one's life. The decision that this man makes also determines whether he is worthy of his sufferings or not. In this sense, Frankl concluded that what sort of person each prisoner became was a result of his inner decision and not the effect of camp influences alone. Although Frankl stated that there were times during his imprisonment when he questioned the reason for his sufferings, it is clear from his writing that most of his questions in his search for meaning were directed toward comprehending the inner life of humans who struggled under suffering.

Even though sometimes Frankl was not sure whether he could endure his suffering, in general he was aware that his life was worth living. The two things he valued the most were his love for his wife and his passion for science. Interestingly, the value of the former was not limited to the idea that his wife might still be alive and the possibility that somehow, they would reunite. In fact, at that time he did not know whether his wife was alive or dead and had no way to find out. Nevertheless, Frankl valued the feeling of love he felt when he thought about his wife. Once, when he was doing his camp labor, his mind wandered to his wife's image. The imagination was so vivid that he could hear her answering him and see her smile and her figure. He (1985) wrote about that moment:

"For the first time in my life I saw the truth as it is set into song by so many poets, proclaimed as the final wisdom by so many thinkers. The truth-that love is the 
ultimate and the highest goal to which man can aspire. Then I grasped the meaning of the greatest secret that human poetry and human thought and belief have to impart: The salvation of man is through love and in love. I understood how a man who has nothing left in this world still may know bliss, be it only for a brief moment, in the contemplation of his beloved.".

Second, Frankl's passion for science and for his work helped him through his suffering. The most valued belonging that he tried to preserve from seizure by the camp guards was the manuscript of his scientific work. He tried to protect the manuscript with his life, but the time came when his life was at stake if he would not give up his work. Although he had lost his manuscript, his mind was still working to remember and develop his writing. When Frankl was suffering from a fever and nearly died, he explained in his book, what kept him alive was thinking about the manuscript. Sometimes, when he became acutely disgusted with camp life, he forced himself to think about another subject; on most of these occasions, he envisioned himself standing at the front of a pleasant classroom, giving a lecture about the psychology of camp prisoners. By this method, he succeeded to rise above his dull, demoralizing situation and above suffering.

We can see that Frankl's reasons to live were internal and thus were not easily broken by external forces, even when the objects that represented these reasons were removed. The values that gave him a reason to live were also long-term aspirations that fueled him with hope for his life after the camp. Once he was liberated, his main purpose in life was to help people to find their own meaning in life through his psychotherapy.

Wiesel's newfound meaning, as already noted, was to spread a message of peace and promote humanity. However, this purpose did not emerge until after he had survived the concentration camp. Wiesel entered the camp as a young boy with a naïve religious faith. He was a devoted Jew, and his main interest as an adolescent was in his lessons about Judaism. However, when he entered the camp he realized that humans had the capacity to kill and to torment each other in order to live. He wondered: What was the point of taking thousands of people's lives? Why were people elsewhere in the world not doing anything to stop the genocide? Where was God when children were hanged and burned? If God did exist, how He could let such cruelty happen to those who believed in Him?

In contrast to Frankl, who found new meaning in life during his imprisonment, Wiesel found it after his liberation. Even though he questioned the existence of God, Wiesel maintained his faithfulness to Judaism, praying just as his father and his ancestors had done. Wiesel wrote in his autobiography that what motivated him to stay alive was the presence of his father. He was actually less afraid of death than of physical suffering. In the camp, he was very close to his father, especially because they thought they were the last surviving members of their family. Wiesel, who had always adored his father, felt that in the camp he finally had his father to himself. They were closer than ever and depended on each other. Because of his father, he had to live, and because of Elie, his father tried not to die. 
On one occasion, the two were transferred to another camp and needed to walk barefoot on a snowy winter day. Wiesel had just had foot surgery and almost gave up walking due to fever and pain. However, his father's encouragement kept him going. He wrote:

"If I was done, he would lose his role, his authority, his identity. And conversely, without him my life would have neither meaning nor goal”' (Wiesel, 2006).

When his father died, Wiesel could no longer feel anything. He felt that someone had died inside of him, and that someone was himself. He felt free to drift into his own death and had no desire to live. Wiesel remained in this state until the camp's liberation. For a couple days after being liberated, he still could not find meaning in his new status as a free man. Later, after he settled in France and met other child and adolescent survivors, he started to become able to make sense of his thoughts and emotions about the Holocaust experience. One important moment in his journey to finding meaning in life was his meeting with a bright Jewish tutor who challenged him to renew his interest in religious study. At this time, he also developed his interests in music, philosophy, humanities, and writing and made them part of his life purpose.

\section{Background Differences Contributing to the Journey of Finding the Meaning}

Both Frankl and Wiesel experienced posttraumatic growth. Both also found a new meaning in their lives. For Frankl, it was to help people to find and pursue meaning in life, mostly through his practice of Logotherapy. For Wiesel, it was to promote peace and to raise his voice on behalf of victims who cannot ask for help for themselves. However, the two underwent different journeys in their search for meaning. What aspects of their background or experiences could have contributed to these differences?

First, Frankl and Wiesel were at different developmental stages when they entered the concentration camp. Frankl was 39 years old, on the verge of becoming a middle-aged adult; Wiesel was just 15. Studies have found a greater presence of perceived meaning as people grow older, whereas those at earlier life stages reported a more searching for meaning and less sense of the presence of meaning (Reker, 2005; Steger et al., 2009). From a developmental point of view, these findings are understandable. According to Erikson (Feist \& Feist, 2008), younger people expend considerable resources on exploring who they are, what they like to do, and with whom they want to become intimate. Therefore, their greater extent of searching for meaning is actually related to their developmental tasks. Furthermore, although by age 11 young people can think abstractly, in most adolescents this way of thinking is not yet fully developed (Papalia, Olds, \& Feldman, 2009). Hence, the age difference helps to explain why, in comparison to Frankl, Wiesel seemed to struggle more to find meaning while in the camp.

Second, differences in life circumstances before entering the camp led to different exposure to Nazism. Frankl lived and worked with people from non-Jewish as well as Jewish backgrounds. Furthermore, because he lived in Austria very close to Germany, even before his imprisonment he had direct experiences of being discriminated against and treated poorly by Nazis because of his Jewish identity. For example, in early 1938 when the Nazis started to 
take over Austria, he was prohibited from treating Aryan patients, and later he was allowed to work only in the hospital designated for Jewish people. In 1942, Frankl and his family were deported to a Jewish ghetto.

In contrast, Wiesel spent most of his first 15 years in a closed Jewish community in Sighet, Romania, where the majority of his neighbors were very committed to Judaism. He too was very devoted to his religion and even developed a keen interest in Kabbalah, or Jewish mysticism. Not until 1941 did Wiesel directly experience the terror of Nazism, when more than a thousand "foreign" Jews were deported to Poland, including some of his neighbors. One person managed to escape from the deportation camp and returned to Wiesel's neighborhood, but when he described the Nazis' brutality and tried to warn his former neighbors, no one believed him. Whereas Frankl's intensity of exposure to the horrors of Nazism increased gradually until he entered the camp, for Wiesel the experience was much more sudden when he and his family were removed from their neighborhood in 1944.

Third, the two men's previous professions made their situations in the concentration camp somewhat different. Whereas Wiesel was only a student, Frankl, having already worked as a psychiatrist, was in a slightly "better" position than most of his fellow prisoners. Although he also had to do hard labor, due to his medical skills he was sometimes assigned to work at the camp hospital and attend to the sick. Being a doctor also gave him the opportunity to befriend some kapos, or prisoner functionaries, who were important authority figures in the camp. Moreover, his psychiatry background enabled him to have a better understanding of the human mind and of human sorrow, which aided his journey to coming to terms with his suffering and loss.

\section{Conclusion}

Our review of the autobiographies of Viktor Frankl and Elie Wiesel shows that they experienced positive development in every domain of posttraumatic growth. Their process of searching for and finding a new sense of meaning was central to their posttraumatic growth experiences. Both of them questioned the suffering they witnessed and endured; Frankl tried to understand the inner life of suffering humans, whereas the nature of Wiesel's faith was transformed. Frankl's love for his wife and his passion for science empowered him to rise above his sufferings, not only motivating him to survive but helping him to find meaning even during his dark days in a concentration camp. Wiesel, on the other hand, found that the close companionship of his father was the sole reason for him to hold on to life. He thus almost lost his will to live when his father passed away and regained it only after being liberated. The differences between Frankl and Wiesel's journeys to finding meaning in life might be attributable to some differences in their background, such as their age, their previous exposure to Nazism, and their profession. After he became free again, Frankl's driving purpose was to help people to find their own meaning in life; for Wiesel, it was to spread the message of peace and promote humanity. 
Some limitations of the study should be considered in interpreting our findings. Frankl and Wiesel's autobiographies contain very rich narratives of their camp experiences, which help the reader to appreciate their process of searching for meaning in life. However, in his autobiography Wiesel also told stories of his childhood and of his life after liberation, making it easier for the reader to observe the before and after experience of his psychological growth. Frankl's autobiography, on the other hand, focused more on his thoughts, feelings, and lessons learned from his time in the camp, but less on his life before or after imprisonment. This limited availability of information may affect the depth of our analysis and interpretation.

To date, posttraumatic growth has been studied mostly by empirical methods, which are less adept in capturing survivors' subjective experiences. Psychobiography allows readers to study and appreciate Holocaust survivors' narratives in a more in-depth, personal, and reflective manner. Clinicians could use this knowledge to foster clients' posttraumatic growth in their therapeutic work or, in broader settings, to help people in societies with histories of mass violence or genocide to cope with their trauma. Clinicians could draw on the examples described here to provide an environment where survivors can talk openly about their internal struggles, help them deal with emotional distress, and encourage them to engage in deliberate cognitive processing and to focus more on the struggle rather than on the suffering.

Several techniques and assignments have been suggested to promote posttraumatic growth when working with survivors (Tedeschi et al., 2015). First, clinicians are encouraged to listen empathetically to survivors' narratives without necessarily trying to solve their problem, while at the same time reinforcing the themes of growth that survivors mention. Second, clinicians must be sensitive as to how and when they choose to highlight opportunities for growth. One suggestion is to use metaphors to reflect on survivors' stories, as traumatic events are not easy to discuss in a straightforward manner. However, discussing the possibility of growth very early in the course of therapy is not suggested, because at the outset victims have more immediate psychological needs that must be met, such as emotional catharsis. Third, providing psychoeducation about normal responses to traumatic events can help survivors to understand their experiences and emotions. Fourth, it is also useful to expose the survivors to posttraumatic growth role models and to use group settings at later stages of therapy, as these methods will help survivors to recognize the possibility of growing. Fifth, assignments such as expressive writing and self-monitoring are very often useful in helping clients to process their emotions as well as to construct their beliefs about the aftermath of the trauma.

As for general readers, this work may help them to gain a deeper understanding of the subject as well as to grow in empathy. This study elucidates how notable Holocaust survivors transformed their suffering into posttraumatic growth. Furthermore, the lessons learned could help clinicians, individuals, and members of society in general to reflect on personal or collective crises that they have encountered and to use this study as a reference on how to rebuild meaning amidst the hardships of life. 


\section{References}

Calhoun, L. G. \& Tedeschi, R. G. (2001). Posttraumatic growth: the positive lessons of loss. In R. A. Neimeyer (Ed.), Meaning reconstruction \& the experience of loss (pp. 157-172). Washington, DC: American Psychological Association.

Calhoun, L. G. \& Tedeschi, R. (2006). The foundations of posttraumatic growth: an expanded framework. In L. G. Calhoun \& R. G. Tedeschi (Eds.), Handbook of posttraumatic growth: research and practice (pp. 123). Mahwah, NJ: Erlbaum.

Danieli, Y. (2007). Assessing trauma across cultures from a multigenerational perspective. In J. P. Wilson \& C. S. Tang (Eds.), Cross-cultural assessment of psychological trauma and PTSD, international and cultural psychology series. Boston, MA: Springer.

du Plessis, C. (2017). The method of psychobiography: Presenting a step-wise approach. Qualitative Research in Psychology, 14(2), 216-237. doi: 10.1080/14780887.2017.1284290.

Elms, A. C. (2007). Psychobiography and case study methods. In R. W. Robins, R. C. Fraley \& R. F. Krueger (Ed.), Handbook of research method in personality psychology. New York, NY: The Guildford Press.

Feist, J. \& Feist, G. J. (2008). Theories of personality (7th ed.). Boston, MA: McGraw-Hill.

Frankl, V. E. (1985). Man's search for meaning: Revised and updated. New York, NY: Washington Square Press.

Janoff-Bulman, R. (2006). Schema-change perspectives on posttraumatic growth. In L. G. Calhoun \& R. G. Tedeschi (Eds.), Handbook of posttraumatic growth: Research \& practice (pp. 81-99). Mahwah, NJ: Lawrence Erlbaum Associates Inc.

Joseph, S., \& Linley, P. A. (2005). Positive adjustment to threatening events: an organismic valuing theory of growth through adversity. Review of General Psychology, 9(3), 262-280. doi: 10.1037/10892680.9.3.262.

Kobasa, S. C. (1979). Stressful life events, personality, and health: an -inquiry into hardiness. Journal of Personality and Social Psychology, 37(1), 1-11. doi: 10.1037/0022-3514.37.1.1.

Kovary, Z. (2011). Psychobiography as a method. Europe's Journal of Psychology, 7(4), 739-777. doi: 10.5964/ejopv7i4.162.

Lev-Wiesel, R. \& Amir, M. (2003). Posttraumatic growth among Holocaust child survivors. Journal of Loss and Trauma, 8(4), 229-237. doi: 10.1080/15325020305884.

Linley, P. A. \& Joseph, S. (2011). Meaning in life and posttraumatic growth. Journal of Loss and Trauma, 16(2), 150-159. doi: 10.1080/15325024.2010.519287.

Martela, F. \& Steger, M. F. (2016). The three meanings of meaning in life: distinguishing coherence, purpose, and significance. The Journal of Positive Psychology, 11(5), 531-545. doi: 10.1080/17439760.2015.1137623.

Papalia, D. E., Old, S. W., \& Feldman, R. D. (2009). Human development. In New-York. New York, NY: McGraw-Hill.

Reker, G. T. (2005). Meaning in life of young, middle-aged, and older adults: factorial validity, age, and gender invariance of the Personal Meaning Index (PMI). Personality and Individual Differences, 38(1), 71-85. doi: 10.1016/j.paid.2004.03.010.

Rutter, M. (1987). Psychosocial resilience and protective mechanisms. American Journal of Orthopsychiatry, 57(3), 316-331. doi: 10.1111/j.1939-0025.1987.tb03541.

Steger, M. F., Frazier, P., Oishi, S., \& Kaler, M. (2006). The meaning in life questionnaire: assessing the presence of and search for meaning in life. Journal of Counseling Psychology, 53(1), 80-93. doi: 10.1037/0022-0167.53.1.80.

Steger, M. F., Oishi, S., \& Kashdan, T. B. (2009). Meaning in life across the life span: levels and correlates of meaning in life from emerging adulthood to older adulthood. The Journal of Positive Psychology, 4(1), 43-52. doi: 10.1080/17439760802303127.

Tedeschi, R. G. \& Calhoun, L. G. (2004). Posttraumatic growth: Conceptual foundations and empirical evidence. Psychological Inquiry, 15(1), 1-18. doi: 10.1207/s15327965pli1501_01. 
Tedeschi, R. G., Calhoun, L. G., \& Groleau, J. M. (2015). Clinical applications of posttraumatic growth. In S. Joseph (Ed.), Positive psychology in practice: Promoting human flourishing in work, health, education, and everyday life (2nd ed.). Hoboken, NJ: John Wiley \& Sons Inc.

Tedeschi, R. G., Cann, A., Taku, K., Senol-Durak, E., \& Calhoun, L. G. (2017). The posttraumatic growth inventory: A revision integrating existential and spiritual change. Journal of Traumatic Stress, 30(1), 1118. doi: $10.1002 /$ jts.22155.

Triplett, K. N., Tedeschi, R. G., Cann, A., Calhoun, L. G., \& Reeve, C. L. (2012). Posttraumatic growth, meaning in life, and life satisfaction in response to trauma. Psychological Trauma: Theory, Research, Practice, and Policy, 4(4), 400-410. doi: 10.1037/a0024204.

Vesely, A. (Director), \& Cimiluca, M., \& Vesely, A. (Producers). (2010). Viktor and I: An Alexander Vesely film.[Motion picture]. California: Noetic Films.

Wiesel, E. (1986, December 10). Nobel prize acceptance speech. Retrieved from https://www.nobelprize.org/nobel_prizes/peace/laureates/1986/wiesel-acceptance_en.html.

Wiesel, E. (2006). Night. New York, NY: Hill and Wang.

Wiesel, E. (2010). All rivers run to the sea: memoirs. New York, NY: Penguin Random House. 